\title{
Standoff Situations and the Fifth
}

\section{Amendment}

In Miranda v. Arizona, ${ }^{1}$ the Supreme Court attempted to neutralize the atmosphere of compulsion that it detected in custodial police interrogation ${ }^{2}$ by ordering that the police inform suspects of their constitutional rights before interrogation. ${ }^{3}$ Since that decision, courts have considered whether "Miranda warnings" should be given in a variety of other factual settings involving police-suspect encounters. ${ }^{5}$ In deciding whether an individual is

\section{384 U.S. 436 (1966).}

2. The Court described this compulsion in the following terms: "[T]he very fact of custodial interrogation exacts a heavy toll on individual liberty and trades on the weakness of individuals . . . It is obvious that . . . an interrogation environment is created for no purpose other than to subjugate the individual to the will of his examiner." Id. at 455, 457 (footnote omitted). For descriptions of the coercive aspects of custodial interrogation, see Brief of the American Civil Liberties Union (ACLU), Amicus Curiae, at 13-20, Miranda v. Arizona, 384 U.S. 436 (1966) (finding custodial interrogation "inherently compelling"); Kamisar, Equal Justice in the Gatehouses and Mansions of American Criminal Procedure, in CRIMINAL JUSTICE IN OUR TIME 1, 31-32 (A. Howard ed. 1965). But see 8 J. WIGMORE, EVIDENCE IN TRIALS AT COMMON LAW $\S 2252$, at 329 n.27 (McNaughton rev. 1961) (because police lack legal authority to compel confessions, right against self-incrimination does not apply at police station).

3. "[The suspect] must be warned prior to any questioning that he has the right to remain silent, that anything he says can be used against him in a court of law, that he has the right to the presence of an attorney, and that if he cannot afford an attorney one will be appointed for him prior to any questioning if he so desires." 384 U.S. at 479. Cf. Brief of the ACLU, Amicus Curiae, at 3 (advocating that presence of counsel be required to protect privilege against self-incrimination).

4. In order to comply with Miranda, police officers typically carry cards with some version of the following set of warnings printed on them:

(1) You have the right to remain silent.

(2) Anything you say can and will be used against you in a court of law.

(3) You have the right to talk to a lawyer and have him present with you while you are

being questioned.

(4) If you cannot afford to hire a lawyer, one will be appointed to represent you before any questioning, if you wish one.

P. WESTON \& K. WELLS, CRIMINAL INVESTIGATION 179 (1970).

The police obtain waivers of the Miranda rights by asking the following questions immediately after reading the above warnings:

(1) Do you understand each of these rights I have explained to you?

(2) Having these rights in mind, do you wish to talk to us now?

Id.; J. HORGAN, CRIMINAL INVESTIGATION 61 (1974).

5. The Supreme Court has held that Miranda governs many of these settings. See, e.g., Estelle v. Smith, 101 S. Ct. 1886 (1981) (interview conducted pursuant to court order by state-employed psychiatrist to determine defendant's competency to stand trial); Orozco v. Texas, 394 U.S. 324 (1969) (police interrogation of arrested suspect in his own bedroom); Mathis v. United States, 391 U.S. 1 (1968) (interrogation by IRS agents of prison inmate regarding matter unrelated to sentence he was serving at that time). See generally p. 360 infra. The Court has declined to apply Miranda in other instances, however. See, e.g., Oregon v. Mathiason, 429 U.S. 492 (1977) (interrogation of suspect who came voluntarily to police station at request of police); United States v. Mandujano, 425 U.S. 564 (1976) (grand jury testimony of subpoenaed witness); Beckwith v. United States, 425 U.S. 341 (1976) (interrogation of individual suspected of tax fraud conducted in private residence by IRS agents); Baxter v. Palmigiano, 425 U.S. 308 (1976) (interrogation at prison disciplinary hearing that was not part of criminal prosecution); see also Annot., 46 L. Ed. 2d 903 (1977) (collecting post-Miranda Supreme Court cases bearing on Miranda issues); Annot., 31 A.L.R.3d 565 (1970) (collecting federal 
entitled to these warnings, courts have implicitly assumed that a criminal suspect can be informed of his rights prior to interrogation without adverse effect on collateral police objectives. In practice, however, this assumption is not always well founded. In "standoff" situations, ${ }^{6}$ where the police communicate with a suspect in order to obtain his surrender, administration of Miranda warnings is likely to frustrate efforts to resolve the crisis peacefully.?

This Note argues that although standoff situations evoke the same concerns for a suspect's Fifth Amendment right against self-incrimination ${ }^{8}$ as those addressed in Miranda, giving the suspect Miranda warnings in such situations produces undesirable results. As a solution, the Note proposes the following per se rule: whenever the police have probable cause to arrest a suspect, and engage him in conversation in order to bring about his surrender, any incriminating statements that the suspect may make during the conversation may not be used against him at trial.

\section{The Problem of a Barricaded Suspect}

In the classic police interrogation setting, the interaction between police officer and suspect involves a single police function-the investigation of crime. ${ }^{9}$ In standoff settings, by contrast, the police perform non-investigative, "peacekeeping" duties ${ }^{10}$ in addition to their usual roles as interro-

and state cases on custodial interrogation).

6. This Note will use the term "standoff situation" to mean a confrontation between the police and a suspect in which the police have probable cause to arrest and are in sufficient proximity to communicate with the suspect and physically prevent him from escaping, but are temporarily prevented from carrying out the formal arrest because they lack immediate physical control over him. See pp. 346-47 infra. The term "standoff suspect" will refer to the suspect involved in a standoff situation.

7. This conclusion rests on the assumption that informing such a suspect of his right to remain silent and warning him that anything he says can be used against him in court will discourage him from talking to the police and thereby impair successful negotiation. See United States v. Mesa, 638 F.2d 582, 588 n.5 (3d Cir. 1980) (opinion of Seitz, C.J.) (emphasizing antagonistic nature of Miranda warnings).

8. The Fifth Amendment makes no explicit reference to a "right against self-incrimination." U.S. CONST. amend. V ("No person . . . shall be compelled in any criminal case to be a witness against himself . . ..") Indeed, the term "self-incrimination" "seems to be of twentieth-century vintage." L. LEVY, ORIGINS OF THE FIFTH AMENDMENT viii (1968). The term, however, is familiar and is therefore a convenient shorthand device.

9. See A. AUbRY \& R. CAPUTO, CRIMINAL INTERROGATION 39 (1965) (characterizing interrogation as "germane to the parent field of investigation"); J. HORGAN, supra note 4, at 59 (1974) (defining interrogation as "a process of probing and gathering available data in crime solving"). The investigatory nature of police interrogation is also revealed by manuals designed to assist police in investigating crime. See, e.g., F. INBAU \& F. REID, CRIMINAL INTERROGATION AND CONFESSIONS 11 (2d ed. 1967) (privacy during interrogation essential to prevent distraction of suspect from investiga(ion); C. O'HARA, FUNDAMENTALS OF CRIMINAL INVESTIGATION 111 (2d ed. 1970) (interrogation room at police station "should be designed . . . to enhanc[e] the concentration of both the interrogator and the subject on the matter under questioning").

10. For the purposes of this Note, "peacekeeping" duties consist of the quotidian activities that the police are called upon to perform in furtherance of an ordered society. J. CAMPBELL, J. SAHID, \& D. STANG, LAW AND ORDER RECONSIDERED 286, 305-06 (1969). See AMERICAN BAR ASSOCIATION, 
gators. Traditional Miranda doctrine, developed with conventional interrogation in mind, fails to deal adequately with these more complicated circumstances.

\section{A. A Paradigmatic Case}

The recent case of United States v. Mesa ${ }^{11}$ graphically illustrates the complexity of situations in which police perform more than a purely investigative function. The case involved the arrest of Rigoberto Mesa, whom the FBI believed was responsible for two shootings. ${ }^{12}$ FBI agents went to a motel where Mesa was staying in order to arrest him. Mesa had barricaded himself in his room and was apparently armed, however, and before the agents could carry out the arrest they had to engage in an extended conversation with him. ${ }^{13}$ The focal point of this conversation was a three and one-half hour telephone discussion ${ }^{14}$ between Mesa and Theodore Viater, an FBI agent with special training in hostage negotiations. Pursuing the objective of calming Mesa down and defusing the situation, Viater portrayed himself as Mesa's friend, and thereby gained the suspect's confidence. ${ }^{15}$ Consequently, Mesa spoke candidly and openly with

THE URBAN POLICE FUNCTION 37 (Tent. Draft 1972) (emphasizing complexity of police role). The police peacekeeping function consumes the overwhelming bulk of police time. See, e.g., H. GOLD. STEIN, POLICING A FREE SOCIETY 32-33 (1977); J. WILSON, VARIETIES OF POLIGE BEhavioR 4 (1968); Bard, Family Crisis Intervention: From Concept to Implementation, in THE CHANGING PO. LICE ROLE 239, 243 (R. Roberg ed. 1976); Goldstein, Introduction, in POLICE CRISIS INTERVENTION 3 (1977); Saunders, The Role of the Police in THE CHANGING POLICE ROLE 74, 83 (R. Roberg ed. 1976).

The peacekeeping and law enforcement responsibilities of police officers frequently overlap. See AMERICAN BAR ASSOCIATION, supra, at 41 (describing relationship between police role as "helper" and as law enforcer); Himmelsbach, Suicide, in POLICE CRISIS INTERVENTION, supra, at 109 (police may encounter suicidal individuals during course of criminal investigation).

11. 487 F. Supp. 562 (D.N.J.), rev'd, 638 F.2d 582 (3d Cir. 1980). See generally 26 VILL. L. REV. 682 (1981) (discussion of Mesa case).

12. The shootings were not fatal and had taken place the previous day. The victims, Mesa's daughter and his common-law wife, told FBI agents that Mesa had shot them. Federal law enforcement officials were involved because the shootings had occurred on the Fort Dix Military Reservation in New Jersey.

13. After evacuating the area around Mesa's room, the agents called to him through a bullhorn, announcing their possession of an arrest warrant and ordering him to surrender. Although the agents repeated this command approximately ten times, Mesa did not respond immediately. Uncertain as to whether Mesa had any hostages and whether he was armed, the agents decided not to attempt an arrest by force. Mesa, in fact, had no hostages but was armed with a pistol. He eventually responded to the agents by passing three handwritten notes out to the agents. In these notes, he stated that he would surrender but that he needed more time to compose himself. He also stated that he did not want to hurt anyone, and that he wanted to see a psychiatrist. Mesa eventually agreed to accept a portable closed-circuit telephone so that the FBI agents could converse with him. By this time, some thirty law enforcement officers had arrived at the motel. 487 F. Supp. at 563-65.

14. See Transcript of Mesa-Viater conversation, reprinted in Appendix to Brief for Appellant 12 76, United States v. Mesa, 638 F.2d 582 (3d Cir. 1980) [hereinafter cited as Mesa transcript).

15. The following speeches by Viater are typical of his attitude throughout the conversation: "Yes Rigoberto, I am listening to you very intently, ah, I can, I have empathy for what you're saying, I understand exactly the things that ah, you are expressing to me . . . . And I want you to know that I 
Viater about many personal matters, including the circumstances surrounding the shootings. ${ }^{16}$ After his surrender and formal arrest, Mesa was given Miranda warnings for the first time. Because the telephone conversation with Viater contained incriminatory statements, ${ }^{17}$ Mesa sought to have the court suppress it at his subsequent trial.

The district court hearing the case found that Mesa's conversation with Viater was subject to the Miranda rule, and therefore did not admit the telephone conversation into evidence. ${ }^{18}$ On appeal, the Third Circuit reversed, applying the traditional dual Miranda criteria of "custody" and "interrogation" to the case. ${ }^{19}$ Mesa had not been subjected to custodial interrogation; the statements he made thus did not warrant Fifth Amendment protection..$^{20}$ Chief Judge Seitz held that Mesa had not been "in custody" when the incriminatory statements were made; because of this conclusion, he found it unnecessary to "address the difficult issue" whether interrogation had occurred. ${ }^{21}$ Judge Adams concurred in the result $^{22}$ but inverted the Chief Judge's reasoning: because Adams decided that no "interrogation" had occurred, ${ }^{23}$ he did not have to "address the difficult issue" whether custody existed. ${ }^{24}$ The inconsistency of the Mesa opinions ${ }^{25}$ illustrates the failure of conventional Miranda analysis to accommodate the peculiarities of the standoff situation.

understand them and I also want you to know and be aware of the fact that I am here to help you .... [A]re you aware of that?" Mesa transcript at 14; "I'm concerned about you Rigoberto, I'm concerned about your welfare, and I'm concerned about your health and I ah want to make absolutely certain that you and $I$ trust each other and we can bring this whole problem . . to a successful resolution. Okay?" id. at 25; "No one will harm you. I make that promise to you and I ah, I make it with the understanding that I can enforce that. No one is going to harm you. I'm controlling this whole situation out here. Do you believe that?" id. at 63 .

16. The following exchange preceded Mesa's description of the shootings:

MESA: What happened yesterday was a provocation. It was a provocation because I am not a

criminal. I am not a criminal. Because I didn't hurt anybody until I went to Viet Nam.

VIATER: Tell me what happened Rigoberto.

MESA: What happened what?

VIATER: Tell me what happened yesterday. What was the provocation?"

Id. at 17 .

17. See note 16 supra. In fact, much of the conversation consists of statements that could have been used against Mesa at trial. During the course of the conversation, Mesa admitted to shooting two people, Mesa transcript at 14,25, and referred many times to the events of the previous day, see, e.g., Mesa transcript at $14,26,56$.

18. 487 F. Supp. at 568.

19. 638 F.2d 582. After the denial of the rehearing, 638 F.2d at 597, Mesa entered a plea of guilty to the charge of assault resulting in serious bodily injury, 18 U.S.C. $\$ 113$ (f).

20. See p. 348 infra.

21. 638 F.2d at 589 (opinion of Seitz, C.J.).

22. Id. at 589.

23. Judge Adams found that the Mesa-Viater conversation did not constitute "interrogation" under Rhode Island v. Innis, 446 U.S. 291 (1980), discussed in note 30 infra, principally because Viater had a non-investigative goal. 638 F.2d at 590 (Adams, J., concurring).

24. 638 F.2d at 590-91 (Adams, J., concurring).

25. The third judge on the Third Circuit panel dissented because he agreed with the District Court's findings that both custody and interrogation had occurred. Id. at 591 (Weiner, J., dissenting). 


\section{B. The Inadequacy of the Traditional Approach}

The test generally used to determine whether the Miranda requirements apply in a given instance ${ }^{26}$ hinges on whether "custodial interrogation," as loosely defined in Miranda, ${ }^{27}$ has occurred. In making this determination, courts typically treat the existence of custody and interrogation as discrete phenomena. ${ }^{28}$ Without both components, custodial interrogation does not exist, and the dictates of Miranda accordingly do not apply. Implementation of this test proves exceedingly problematic in standoff situations, however. Moreover, important policy concerns make the traditional doctrine inappropriate for such settings.

\section{Problems in Applying the Custodial Interrogation Test}

Courts have attempted to isolate inquiries concerning "custody"29 from inquiries concerning "interrogation"

26. See note 5 supra (citing cases involving application of Miranda to various factual settings); sec generally Kamisar, "Custodial Interrogation" Within the Meaning of Miranda, in INSTITUTE OF CONTINUING LEGAL EDCATION, CRIMINAL LAW AND THE CONSTITUTION 335 (1968) (discussing development of Miranda test); Grano, Voluntariness, Free Will, and the Law of Confessions, 65 VA. L. REV. 859, 926 (1979) (same); Smith, The Threshold Question in Applying Miranda: What Constitutes Custodial Interrogation? 25 S.C.L. REV. 699 (1974) (same).

27. The Miranda Court supplied the following definition: "By custodial interrogation, we mean questioning initiated by law enforcement officers after a person has been taken into custody or otherwise deprived of his freedom of action in any significant way." 384 U.S. 436, 444. See also id. at 445, 477, 478 (reiterating this definition).

28. See C. MCCORMICK, HANDBOOK OF THE LAW OF EVIDENCE $\S 152$ (2d ed. 1972) (describing dual nature of typical inquiry in determining applicability of Miranda to given situation). In most custodial interrogation cases, the presence of one of these elements is clear and the inquiry focuses on whether the other is also present. See Rhode Island v. Innis, 446 U.S. 291 (1980) (only issue whether suspect who was arrested, handcuffed, and riding in police car with several officers was interrogated); United States v. Hall, 421 F.2d 540 (2d Cir. 1969) (only issue whether suspect was in custody during interview at his home); $c f$. Brewer v. Williams, 430 U.S. 387 (1977) (issue whether remarks made by officer riding with arraigned defendant while conversing in police car violated defendant's Sixth Amendment right to counsel).

29. See, e.g., Oregon v. Mathiason, 429 U.S. 492 (1977) (suspect who voluntarily came to stationhouse for questioning at request of police not in custody); Beckwith v. United States, 425 U.S. 341 (1976) (individual suspected of tax fraud not in custody when questioned by IRS agents at private residence where he sometimes stayed); Orozco v. Texas, 394 U.S. 324 (1969) (suspect arrested in own bedroom, held in custody for Miranda purposes); Mathis v. United States, 391 U.S. 1 (1968) (prison inmate interrogated by IRS agents regarding matters unrelated to sentence he was serving, held in custody for Miranda purposes).

30. See Rhode Island v. Innis, 446 U.S. 291 (1980). In Innis, police officers riding in a car with an arrested defendant made remarks-ostensibly among themselves-that prompted the defendant to reveal the location of incriminating evidence. The Court held that Innis was not subjected to interrogation because the police officers did not have reason to believe that their remarks would induce him to make a statement. Id. at 302. Compare Rhode Island v. Innis, 446 U.S. 291 (1980) with Commonwealth v. Simala, 434 Pa. 219, 227, 252 A.2d 575, 579 (1969) ("IA]ny question likely to or expected to elicit a confession constitutes interrogation." ") (emphasis supplied). See also Commonwealth v. Brant, 406 N.E.2d 1021, 1026 (Mass.), cert. denied, 449 U.S. 1004 (1980) (applying Innis test and finding statement by police officer to defendant that accomplice had confessed to be interrogation); 9 HOFSTRA L. REV. 691, 708 (1981) (discussing Innis test and criticizing it as unworkable); $71 \mathrm{~J}$. CRIM. L. \& CRIMINOLOGY 466, 473 (1980) (finding Innis test susceptible to wide variety of applications). 
trine. ${ }^{31}$ In the standoff situation, however, these two elements are inextricably intertwined. The conversation occurs solely because the police are attempting to take the suspect into formal custody. If the standoff suspect's custody status were not problematic, the police-suspect conversation-or arguable interrogation-would not take place. The conversation is an integral part of the process of arrest,,$^{32}$ which it is intended to facilitate. In standoff situations, the use of "custody" and "interrogation" as general labels prompting separate all-or-nothing answers obscures the implication of the rights that the Miranda Court intended to protect. The unique nature of these situations demands a less ritualistic analysis.

\section{Conflicting Policy Concerns}

Policy considerations may explain the reluctance of courts to extend Fifth Amendment protection to standoff settings. Although the panel majority in Mesa ostensibly based its holding of admissibility on Miranda, both opinions also emphasized the explosiveness of the situation. ${ }^{33}$ Eager to ensure that police would treat future standoff situations in the peaceful way that the FBI handled the confrontation in Mesa, the panel majority feared that a suppression holding under Miranda would present the police with a "delicate and difficult choice" between investigatory and peacekeeping goals, a choice that would compromise the preeminent purpose of crisis resolution. ${ }^{34}$ According to Chief Judge Seitz, such a holding would force the police to balance the value of information obtained during the conversation against the probability that the suspect might "react violently to the antagonistic-sounding Miranda warnings." ${ }^{35}$

Judge Adams also noted this dilemma, ${ }^{36}$ but his opinion indicates that

31. See note 28 supra.

32. Because of the extended confrontational nature of the standoff situation, the conversation could not be considered to be "normally attendant to arrest and custody," a category that the Innis Court excluded in dicta from its definition of "interrogation." 446 U.S. at 301 . Moreover, unlike the standoff situation, Innis involved circumstances where custody was utterly unproblematic. See note 28 supra.

33. 638 F.2d at 588 (opinion of Seitz, C.J.); jd. at 589 (Adams, J., concurring).

34. Id. at 588 (opinion of Seitz, C.J.) (requiring suppression in this case would place law enforcement officals in extremely difficult position); id. at 590 (Adams, J., concurring) (when attempting to save lives through surrender negotiations, police should not have to make "pressured judgment" whether Miranda warnings will deter suspect from talking).

35. Id. at 588 (opinion of Seitz, C.J.). Hostage negotiators are trained to maintain a congenial attitude toward hostage-takers during negotiations. See G. MAHER, HOSTAGE 14, 36 (1977) (negotiator should sound sincere and sympathize with hostage-taker's problem); M. MIRON \& A. GOLDSTEIN, HOSTAGE 93 (1978) (negotiator should be skilled at conciliation, compromise, and bargaining); Davidson, Anxiety and Authority: Psychological Aspects for Police in Hostage Negotiations, $9 \mathrm{~J}$. POLICE SCI. \& AD. 35, 37 (1981) (negotiator should be patient, clear-headed, and have warm personality); $c f$. Goldstein, Crisis Intervention Manual for Police, in POLICE CRISIS INTERVENTION 16-20 (1977) (describing conciliatory methods recommended to police for resolving crises).

36. See note 34 supra. 
other policy considerations militate in favor of the suppression of surrender-negotiation statements. For example, admitting such statements into evidence might impair the ability of future hostage negotiators to generate the atmosphere of trust necessary to resolve the crisis. ${ }^{37}$ Thus, if the statements were admissible, prosecutors might be tempted to use them to obtain a conviction at the expense of future standoff negotiation efforts. ${ }^{38}$

\section{Applying the Fifth Amendment to Standoff Situations}

The difficulty of applying traditional custodial interrogation analysis to standoff cases, and the importance of non-constitutional policy considerations in such cases prompt a close comparison between traditional $\mathrm{Mi}$ randa-type interrogation and the standoff setting. This examination reveals that both settings in fact implicate Fifth Amendment rights.

\section{A. Miranda and the Right Against Self-Incrimination}

In Miranda, the Supreme Court held that the Fifth Amendment right against self-incrimination is fundamental to the criminal justice system. ${ }^{39}$ It emphasized that the root of this right lies in a concern for the dignity of the individual..$^{40}$ Because the state must respect the individual, the Fifth Amendment requires that the government rely on its own independent efforts to invoke criminal sanctions against a citizen, rather than on a confession extracted by compulsion, ${ }^{41}$ even if there is no reason to doubt

37. 638 F.2d at 591 (Adams, J., concurring) ("Once alerted to the possibility that the government may abuse or breach its assurances of aid and friendship, suspects may be more reluctant to negotiate with the police.")

38. Instead of resolving this dilemma through a judicially imposed device, Judge $A$ dams concluded that "[t]he final judgment . . . regarding the fairness or desirability of recording and introducing statements obtained in situations such as the present one is . . . a policy decision for the executive branch." Id. This Note reaches a different conclusion. For discussion of the competence of the courts to make this decision, see pp. 358-60 infra.

39. 384 U.S. at 468 . The literature generally refers to this provision of the Fifth Amendment as a "privilege" rather than a "right." Even staunch supporters of the provision employ the less reverent term. See, e.g., Kamisar, Brewer v. Williams, Massiah, and Miranda: What is "Interrogation?" When Does it Matter? in Police InTERRogation AND Confessions 139 (1980); Amsterdam, The Supreme Court and the Rights of Suspects in Criminal Cases, 45 N.Y.U. L. REv. 785 (1970). Indeed, the Miranda Court itself called the right against self-incrimination a "privilege." See L. LEVY, supra note 8 , at viii.

40. 384 U.S. at 457,460 . The Miranda majority cited many other cases espousing this view of the origins of the Fifth Amendment, including Tehan v. Shott, 382 U.S. 406, 414-15 n.12 (1966); Murphy v. Waterfront Comm'n, 378 U.S. 52, $55-57$ n.5 (1964); United States v. Grunewald, 233 F.2d 556, 579, 581-82 (Frank, J., dissenting), rev'd, 353 U.S. 391 (1957). See L. LEVY, supra note 8, at 330 (1968) (historical antecedents of Fifth Amendment reflect "natural repugnance to self-destruction"); Schrock, Welsh \& Collins, Interrogational Rights: Reflections on Miranda v. Arizona, 52 S. CAL. L. REV. 1, $42 \mathrm{n} .174$ (1978) (right against self-incrimination stems from respect that government owes individual). But see Grano, Rhode Island v. Innis: A Need to Reconsider the Constitutional Premises Underlying the Law of Confessions, 17 AM. CRIM. L. REV. 1, 47 n.290 (1979) (contesting position that government owes individual such respect).

41. 384 U.S. at 460 (citing Chambers v. Florida, 309 U.S. 227, 235-38); see also 8 J. WIGMORE, 
the accuracy of that confession..$^{42}$ Miranda warnings were designed to protect the right against self-incrimination by combatting the "inherently compelling pressures" of custodial interrogation and permitting "a full opportunity to exercise the privilege . . . " 43 Reaching both involuntary and voluntary confessions, ${ }^{44}$ the Court attempted to ensure that each suspect know at least of the existence of his rights before he confessed. ${ }^{45}$

The Miranda Court was particularly concerned with interrogation techniques that tend to discourage suspects from invoking their right against self-incrimination. ${ }^{46}$ For example, one of these techniques calls for the interrogator to profess friendship for the suspect, whose best interests the officer claims to serve. ${ }^{47}$ Although this tactic might extract a confession that would be admissible under the traditional "voluntariness" test, ${ }^{48}$ the

supra note $2, \S 2251$, at 317 (government should "shoulder the entire load" necessary to convict defendants).

42. 384 U.S. at 464 n.33. See Rogers v. Richmond, 365 U.S. 534, 544 (1961) (truth of defendant's confession held irrelevant in determining voluntariness of confession under due process clause of Fourteenth Amendment).

43. 384 U.S. at 467.

44. Id. at 457.

45. Thus, the Miranda Court was not concerned that some suspects might already be familiar with their constitutional rights, independent of any warnings. Id. at 468 .

46. Id. at 448-55. The Court emphasized that "the modern practice of in-custody interrogation is psychologically rather than physically oriented." Id. at 448 . To illustrate the effects of such interrogation, the Court quoted extensively from various police manuals describing interrogation procedures. See note 9 supra.

47. 384 U.S. at 450-52. In this technique, the interrogator assumes an attitude of sympathy for the suspect and interest in the latter's plight. C. O'HARA, supra note 9, at 110 ("The investigator is not seeking to convict or punish. He is endeavoring to establish the facts of the case; . . to help the subject to straighten himself out . . . ."); R. ROYAL \& S. SCHUTT, THE GENTLE ART OF INTERVIEWING AND INTERROGATION 61-62 (1976) (recommending that interrogator "establish a friendly and trusting attitude on the part of the subject"). For discussions that are critical of this technique, see Spano v. New York, 360 U.S. 315 (1959) (disapproving confession given to police officer who exploited his childhood friendship with defendant); Leyra v. Denno, 347 U.S. 556 (1954) (disapproving confession given to psychiatrist posing as doctor intending to help defendant plagued by headaches); White, Police Trickery in Inducing Confessions, 127 U. PA. L. REV. 581, 614-17 (1979) (discussing "pretended friend" technique).

48. Before Malloy v. Hogan, 378 U.S. 1 (1964), which announced the applicability of the Fifth Amendment to the states, the admissibility of confessions had been governed by the due process clause of the Fifth and Fourteenth Amendments. See Paulsen, The Fourteenth Amendment and the Third Degree, 6 STAN. L. REV. 411, 420 (1954) (due process includes right to stand mute without being subjected to pressures of serious human indignities). But see Bram v. United States, 168 U.S. 532 (1897) (federal case confession excluded under self-incrimination provision of Fifth Amendment). Under the due process analysis, a voluntariness test was used to determine the admissibility of confessions. The Supreme Court ultimately abandoned the voluntariness test in Escobedo v. Illinois, 378 U.S. 478 (1964), the precursor to Miranda. O. STEPHENS, THE SuPREME COURT AND CONFESSIONS OF GUILT 122, 127 (1973). The voluntariness test examined whether, given the "totality of the relevant circumstances of a particular situation," the confession was "the product of an essentially free and unconstrained choice by its maker" or the product of an "overborne will." Culombe v. Connecticut, 367 U.S. 568, 602, 606 (1961) (opinion of Frankfurter, J.).

Although the voluntariness test has been criticized for its amorphous nature, see Kamisar, What is an "Involuntary" Confession? Some Comments on Inbau and Reid's Criminal Interrogation and Confessions, 17 RUTGERS L. REV. 728, 742 (1963), the test continues to have supporters. See, e.g., Grano, supra note 26, at 944; Stone, The Miranda Doctrine in the Burger Court, 1977 SUP. CT. REV. 99, 168 (Supreme Court has shown "apparent desire to return, ultimately, to the 'voluntariness' stan- 
use of such a psychological ploy to induce a suspect to relinquish his right against self-incrimination offended the Miranda Court. The suspect would in fact be deceived into incriminating himself; only too late would he realize that his friendly interlocutor was actually an adversary. ${ }^{49}$

\section{B. The Fifth Amendment Protects Standoff Suspects}

The standoff situation involves a form of coercion similar to the psychological techniques that the Miranda Court perceived as threats to the suspect's right to make an unconstrained and informed choice regarding selfincrimination. ${ }^{50}$ In a standoff, the suspect is under pressure ${ }^{5 t}$ to talk to the police, who represent his only link to the outside world and actively encourage him to unburden himself to them on any subject, including the purported crime. ${ }^{52}$ Such efforts by police to cultivate feelings of friendship and trust in the suspect increase the likelihood that he will speak openly about his problems and, in doing so, incriminate himself.

In the conventional interrogation case, Miranda now requires that the suspect receive warnings that preserve his opportunity to invoke the Fifth Amendment. ${ }^{53}$ For his statements to be admissible, the suspect must understand and waive his rights. ${ }^{54}$ The standoff suspect, by contrast, receives no Miranda warnings and may experience a more intense compulsion to speak than he would in a conventional setting. He is less likely to be

dard"). Cf. United States v. Mesa, 638 F.2d 582, 589 (3d Gir. 1980) (opinion of Seitz, C.J.) (statements by armed and barricaded suspect must be voluntary to be admissible). Because Mesa did not raise the voluntariness issue on appeal, however, Seitz did not reach this question.

49. Thus, the Court required the warning "that anything said can and will be used against the individual in court . . . in order to make him aware not only of the privilege [against self-incrimination], but also of the consequences of forgoing it." 384 U.S. at 469.

50. Admittedly, the interrogator at the police station can direct the questioning more effectively than the hostage negotiator can control the subject matter of the standoff conversation. This distinction, however, does not alter the fact that the standoff suspect has a right not to talk to the police at all. Thus, because many suspects cannot appreciate the difference between incriminating and nonincriminating statements, see Escobedo v. Illinois, 378 U.S. 478, 486 (1964) (suspect did not realize that by accusing accomplice of pulling trigger, he was implicating himself in murder), the first $\mathrm{MF}$ randa warning is expressed specifically in terms of a right to remain silent rather than one not to incriminate oneself. See note 4 supra.

51. Indeed, the coercion experienced by an isolated individual completely surrounded by armed police officers is arguably even greater than that inherent in conventional interrogation settings. See $\mathrm{p}$. 353 infra. But see United States v. Mesa, 638 F.2d 582, 588 (3d Cir. 1980) (opinion of Seitz, C.J.) (standoff suspect's ability to move about motel room and not listen to officer's questions precludes coercion).

52. See pp. 346-47 supra.

53. The Miranda Court was not content merely to ensure that the suspect be permitted to assert his rights. Instead, the Court insisted that the police inform the suspect of the existence of those rights. Only then could there be "any assurance of real understanding and intelligent exercise" of these rights, 384 U.S. at 469 , the prerequisite to ensuring that the suspect's statements would be "truly the product of free choice." Id. at 457. See Schrock, Welsh, \& Collins, supra note 40, at 41-42 (interpreting Miranda as effort to preserve governmental respect for responsible choice by criminal suspects).

54. See 384 U.S. at 479 (after warnings, individual may knowingly and intelligently waive his rights). 
aware of the investigatory nature of his conversation with the police. ${ }^{55}$ Moreover, the standoff suspect's understandable fear for his own life ${ }^{56}$ during the confrontation renders him all the more vulnerable to the friendly overtures of a negotiator. ${ }^{57}$ Unless the conversation with the officer during the standoff is suppressed, the suspect will have unwittingly forfeited his right to choose whether to incriminate himself. The apparent friendliness of the police in the standoff situation need not involve conscious deception to implicate the Fifth Amendment interests, ${ }^{58}$ since the government's subsequent use of the conversation retroactively transforms the officer from friend to adversary. ${ }^{59}$

It should be emphasized, however, that recognition of Fifth Amendment concerns in the standoff situation does not imply constitutional condemnation of the police practice of negotiating surrenders. ${ }^{60}$ Although the Miranda Court held that confessions obtained without warnings could not be used at trial, it did not explicitly outlaw any of the police interrogation techniques that it considered responsible for generating an atmosphere of compulsion at the stationhouse, nor did it chastise the police for unconsti-

55. Although the suspect undergoing conventional police interrogation is under pressure to speak because of the immediate police presence in that setting that does not exist in the standoff situation, the police purpose to gather evidence should be much more apparent to the conventional suspect than to the standoff suspect. From the latter's viewpoint, the conversation with the police officer serves primarily as an opportunity to relate his tale of woe to a sympathetic listener. See United States v. Mesa, 638 F.2d 582, 589-90 (3d Cir. 1980) (Adams, J., concurring).

56. Mesa expressed fear for his own safety several times during his conversation with Agent Viater. See, e.g., Mesa transcript at $23,38,44,45,66$. These fears certainly seem justified. As the District Court remarked, "[t]here were only three ways that $\mathrm{Mr}$. Mesa could have left that motel room: dead, injured and under arrest, or uninjured and under arrest." 487 F. Supp. at 566. See also MAHER, supra note 35, at 25 (obvious police activity at standoff scene likely to disconcert emotionally disturbed suspect).

57. A standoff suspect-such as Mesa-with severe emotional problems may be particularly eager to bare his soul to a sympathetic listener. See MAHER, supra note 36 , at 10, 13. Indeed, during his conversation with Agent Viater, Mesa expressed interest in seeing a psychiatrist who would help him talk about his troubles. Mesa transcript at 57-59.

58. The Miranda Court concentrated exclusively on the perspective of the suspect, not that of the police. But see United States v. Henry, 447 U.S. 264, 270-71 (1980) (government violated defendant's Sixth Amendment right to counsel by intentionally creating situation in which defendant would be "likely" to incriminate himself); Rhode Island v. Innis, 446 U.S. 291, 301 (1980) ("interrogation" defined as any words or actions "that the police should know are reasonably likely to elicit an incriminating response").

59. Cf. Brewer v. Williams, 430 U.S. 387 (1977) (officer appealed to suspect to reveal location of victim's body in order to afford her "Christian burial"); Spano v. New York, 360 U.S. 315 (1959) (suspect and police officer to whom he confessed had been boyhood friends); Kamisar, supra note 39, at 169 (comparing Williams and Spano).

60. The reluctance of the Third Circuit to apply the Miranda case to the situation in Mesa may stem from fear of appearing to condemn this practice. See 638 F.2d at 588 (opinion of Seitz, C.J.) (unless warnings needed to protect standoff suspect's Fifth Amendment rights, court will not discourage practice of negotiating surrenders); id. at 597 (Weiner, J., dissenting) (entitlement to warnings does not imply criticism of FBI procedures for standoff situations). See also id. at 598 (Gibbons, J., dissenting from denial of petition for rehearing en banc) (suppression of conversation would not require agents to give warnings to standoff suspects). 
tutional conduct. ${ }^{61}$ Similarly, the courts should be able simultaneously to support police efforts to negotiate surrenders, and to preserve the rights of standoff suspects.

\section{Proposal: A Per Se Ban on Admissibility}

Only a rule that bars outright the use of statements made by a suspect during surrender negotiations in a standoff situation can accommodate the pressing policy concerns inherent in this setting. Imposition of such a rule would reflect the judicial responsibility of designing devices that effectively protect constitutional rights.

\section{A. Means Available to Protect the Rights of Standoff Suspects}

Two different approaches could be employed to protect the Fifth Amendment rights of criminal suspects: (1) administration of traditional Miranda warnings, or (2) exclusion of the conversation without regard to whether warnings are given. A comparison of the policy implications that flow from these two approaches demonstrates the superiority of the per se rule.

\section{Administration of Warnings}

The Supreme Court's response to the need for Fifth Amendment safeguards in police interrogation settings was to require the Miranda warnings. ${ }^{62}$ The same requirement could be extended to standoff situations. In evaluating such an approach, however, it is important to distinguish between the purpose the Miranda majority pursued and the particular procedures it mandated to fulfill that purpose. The Court ordered that the police preface any interrogation with a series of warnings in order to ensure that criminal suspects would understand both the adversarial nature of their situations ${ }^{63}$ and their right not to speak to the police. ${ }^{64}$ The Court anticipated that, having received this information, the suspect could make an unconstrained and informed choice whether to respond to interrogation. ${ }^{65}$

In theory, one might allow the police to decide in each case whether to administer warnings and risk unnecessary violence, or negotiate without

61. On the contrary, the Court expressed appreciation for the difficulties the police face in performing criminal investigations, and denied that it intended to hamper that process in its efforts to protect constitutional rights. 384 U.S. at 477, 481. See Sulger, The Role of the Police in Modern Society, 3 POLICE L.Q., July, 1974, at 5-6 (denying that Miranda decision restrains police).

62. See note 4 supra.

63. 384 U.S. at 469 . See p. 351 supra.

64. See note 4 supra.

65. See p. 352 supra. 
warnings and preclude the use at trial of any statements they obtain..$^{66}$ There are, however, compelling reasons not to adopt such an approach. The volatility of a standoff situation should almost always make peacekeeping concerns preeminent over less immediate investigatory goals until the crisis has been resolved. ${ }^{67} \mathrm{~A}$ rule requiring the police to choose between peacekeeping and crime investigation would needlessly expand their discretion ${ }^{68}$ and might thus distract them from executing procedures that would normally be employed to resolve such a crisis. ${ }^{69} \mathrm{~A}$ heightened risk to the safety of the suspect, the officers, any hostages, and the general public would result. ${ }^{70}$ Furthermore, the great potential for second-guessing police actions in such circumstances would frequently lead to public criticism on either humanitarian or law enforcement grounds, ${ }^{71}$ depending on the choice that was made. Thus, as a policy matter, ${ }^{72}$ Miranda warnings do not constitute a satisfactory device to protect the rights of standoff suspects. $^{73}$

66. Judge Gibbons proposed this solution in his dissent from the denial of rehearing en banc in United States v. Mesa, 638 F.2d 582, 598 (3d Cir. 1980).

67. See p. 349 supra.

68. Of course, the police do enjoy a wide range of discretion in order to cope with the myriad vicissitudes that threaten the stability of society. See $A$. GOLDSTEIN, THE INSANITY DEFENSE 171-75 (1967) (describing "adjudicative" choice of arresting officer whether criminal or civil commitment proceedings should be instituted); H. GOLDSTEIN, supra note 10, at 93, 94 (discussing various forms of discretion); Saunders, supra note 10, at 82 ("[D]iscretion is the better part of peacekeeping.") Some commentators have challenged the legitimacy of police discretion. See, e.g., Goldstein, Police Discretion not to Invoke the Criminal Process: Low-Visibility Decisions in the Administration of Justice, 69 YALE L.J. 543 (1960) (arguing against discretionary non-enforcement of criminal laws); Remington \& Rosenblum, The Criminal Law and the Legislative Process, 1960 U. ILL. L.F. 481 (same). Others have recognized police discretion as inevitable, and have advocated increased rule making as a means to giving the police greater guidance. See, e.g., AMERICAN BAR ASSOCIATION, supra note 10, at 116-33 (1973); K. DAVIS, DisCRETIONARY JUSTICE 80, 222 (1969); PRESIDENT'S COMIMISSION ON LAIV ENFORCEMENT AND ADMINISTRATION OF JUSTICE, THE CHALLENGE OF CRIME IN $\Lambda$ FREE SOCIETY 10304 (1967); LaFave, The Police and Nonenforcement of the Law (pt. 2), 1962 WiSc. L. REV. 179, 238-39.

69. Agent Viater indicated at the suppression hearing in Mesa that he had not considered the possibility of a need for Miranda warnings before he talked to Mesa. Testimony of Theodore Viater, reprinted in Appendix to Brief for Appellant 236, 238, United States v. Mesa, 638 F.2d 582 (3d Cir. 1980). An explicit ruling by a court that the police must decide whether to give warnings in order to preserve any evidence obtained during standoff conversations would force future hostage negotiators to consider that option. See p. 349 supra.

70. The objective of preventing harm to anyone in the area around a standoff led Chief Judge Seitz in Mesa to reject a warnings rule. 638 F.2d at 588-89. Obviously, the suspect himself may be harmed if the police use force; he may also attempt suicide. Indeed, Mesa contemplated the latter action, Mesa transcript at $28,34,55$, which he later said he would have taken, had he not talked to Viater. 638 F.2d at 590 (Adams, J., concurring).

71. The prospect of criticism for choosing the wrong course of action might cause the police to select still a third alternative: rather than risk criticism through negotiation (with or without warnings), the police could choose to take the suspect by force immediately. Again, the peacekeeping function would be sacrificed, though not in favor of any investigatory purpose, since no additional evidence would be revealed. See United States v. Mesa, 638 F.2d 597, 598 (3d Cir. 1980) (Gibbons, J., dissenting from denial of petition for rehearing en banc).

72. See p. 349 supra.

73. Furthermore, Miranda warnings might not provide adequate protection for the constitutional 


\section{Per Se Exclusion of Standoff Conversations}

Instead of requiring that police give standoff suspects Miranda warnings to preserve the admissibility of the conversation, courts could simply hold these conversations inadmissible per se. ${ }^{74}$ Such a rule would be limited to situations where the police have probable cause to arrest a suspect ${ }^{75}$ whom they have surrounded ${ }^{76}$ and with whom they converse in order to facilitate his peaceful, formal arrest. Like the Miranda decision, the rule would preserve the opportunity of the suspect to exercise his right against self-incrimination. ${ }^{77}$

rights of standoff suspects. The warnings-particularly the admonition that anything the suspect says can and will be used against him-are intended to convey to the suspect the adversarial nature of his conversation with the police, in order to protect his right against self-incrimination. See p. 352 supra. In the standoff situation, the officer's appeals to trust and friendship would contradict, if not effectively cancel, this warning. See p. 353 supra. Thus, it seems likely that the warnings would not accomplish the function for which they were designed; the purpose of Miranda, to secure Fifth Amendment rights, would accordingly go unfulfilled.

74. Presumably, such a rule would not affect the admissibility of standoff conversations for impeachment purposes. Cf. Harris v. New York, 401 U.S. 222 (1971) (if trustworthy, statement obtained without Miranda warnings is admissible to attack defendant's credibility as witness).

75. The Miranda Court clearly intended to exempt from its holding interviews where the police lack probable cause to arrest the people they question. 384 U.S. at 477 . ("General on-the-scene questioning ... of citizens in the fact-finding process is not affected by our holding . ...") Probable cause thus becomes a necessary element of the per se rule proposed in this Note. This feature is in accordance with current law. See, e.g., United States v. Welsh, 417 F.2d 361 (5th Cir. 1969) (admissions by suspect before police obtained probable cause to arrest him held not subject to Miranda rule). Compare State v. Morris, 224 Tenn. 437, 456 S.W.2d 840 (1970) (questioning suspect as to whether he was driver of car involved in fatal accident held not subject to Miranda) with 39 TENN. L. REV. 178, 181 (1971) (criticizing Morris court for not finding probable cause, which would have rendered case subject to Miranda requirements).

76. Although the rule proposed here does not require that the police be able to exercise complete physical control over the suspect, its applicability does depend on the capacity of the police to prevent the suspect from escaping. Without substantial limitation on his freedom, the suspect would not be subjected to compulsion of constitutional proportions. See note 27 supra.

77. It is true, of course, that an opposite per se rule could also achieve the result of resolving the police dilemma. Under such a rule, standoff conversations would always be admissible. The California courts have created an emergency exception doctrine that allows police who arrest a suspect to ask the location of a known victim before administering Miranda warnings. Statements then made by the suspect are admissible as evidence, as is the "fruit" of those statements. See People v. Riddle, 83 Cal. App. 3d 563, 148 Cal. Rptr. 170 (1978), cert. denied, 440 U.S. 937 (1979); People v. Dean, 39 Cal. App. 3d 875, 114 Cal. Rptr. 555 (1974); People v. Modesto, 62 Cal. 2d 436, 42 Cal. Rptr. 417, 398 P.2d 753 (1965). The rationale of this doctrine lies in the preeminent purpose of rescuing the victim of a crime from possible harm or death. It reflects the fear that, should the warned suspect invoke his rights, the police might lose their only chance to rescue the victim.

The California emergency doctrine has received the approval of several commentators, especially critics of the Miranda decision. See, e.g., H. FRIENDLY, A Postscript on Miranda, in BENcHMARKS 266, 277 (1967); Traynor, The Devils of Due Process in Criminal Detection, Detention, and Trial, 33 U. CHI. L. REV. 657, 677-78 $n_{c} 86$ (1966). On the other hand, the doctrine has also been attacked as a legal non sequitur, for the paramount need to save lives does not logically establish the admissibility of statements obtained without Miranda warnings. Cf. Graham, What is "Custodial Interrogaiion? ": California's Anticipatory Application of Miranda v. Arizona, 14 U.C.L.A. L. REV. 59, 120 n.324 (1966) (comparing exclusion of unwarned statements obtained during emergencies to statutory immunity); Comment, People v. Dean, Another Swipe at Miranda, 4 U. SAN FERN. V.L. REV. 85, 96 (1975) (criticizing reasoning in Dean). The real dilemma posed by such an emergency case is not between the victim's life and the defendant's constitutional rights, but rather between the latter's 
Nothing in the Miranda decision precludes a per se ban on the admissibility of standoff negotiations. ${ }^{78}$ Fifth Amendment infringements do not occur until the state attempts to use compelled confessions in criminal cases. ${ }^{79}$ Accordingly, Miranda warnings possess no constitutional significance independent of their purpose. A police officer's failure to administer them does not in itself, therefore, violate the Constitution. ${ }^{80}$ The opposite interpretation would require one to condemn as a Fifth Amendment violation the officer's decision to talk the standoff suspect into surrender. ${ }^{81}$

Unlike the warnings alternative, the per se rule would eliminate any incentive the police might have to curtail their peacekeeping function in order to further their efforts to obtain evidence. ${ }^{82}$ This rule would allow the police to exercise the discretion necessary to resolve standoff situations peacefully ${ }^{83}$ Yet the rule also recognizes that this discretion cannot dictate the scope of constitutional rights. ${ }^{84}$ The rule would apply only to state-

rights and the state's interest in using his statements to convict him. See Graham, supra, at 120.

78. The availability of such an alternative may not be self-evident, because after fifteen years of use, the Miranda warnings have come to be viewed as virtually synonymous with Fifth $\Lambda$ mendment rights. See United States v. Mesa, 638 F.2d 582 (3d Cir. 1980) (not considering per se exclusionary rule).

79. Only when a suspect's statements are used in court do they become legally "incriminating." Thus, the doctrine of use immunity permits the government to compel a witness to testify in return for a guarantee that none of the testimony will be used directly or indirectly in any subsequent prosecution of the witness. See Kastigar v. United States, 406 U.S. 441, 453 (1972) (grant of immunity coextensive with right against self-incrimination because immunity prohibits prosecutorial use of compelled testimony). But see Amsterdam, supra note 39, at 799 (privilege against self-incrimination "entirely insulates a suspect from being required to give incriminating responses; it does not merely shield him from the incriminating use of those responses").

Professor Amsterdam fears that this interpretation of the scope of the Fifth Amendment will not deter the police from engaging in "abusive conduct" toward arrested suspects. Id. at 804 . But even if the Fifth $A$ mendment extends only to the use of incriminating statements, as argued here, the due process clause continues to protect suspects from police abuse. See Paulsen, supra note 48, at 420; Ritchie, Compulsion that Violates the Fifth Amendment: The Burger Court's Definition, 61 MINN. L. REV. 383, 393 (1977).

80. The second Miranda warning, which explains the consequences of forgoing the right to remain silent, simply informs the suspect that anything he says can and will be used against him in court. 384 U.S. 436,469 (1966). This feature distinguishes the Fifth Amendment from the Fourth, under which the actual police activity of conducting an unreasonable search and seizure represents the locus of constitutional violation. The Fourth Amendment exclusionary rule aims at deterring illegal police activity, see Weeks v. United States, 232 U.S. 383 (1914), whereas the Fifth Amendment exclusionary rule rises out of the constitutional prohibition of governmental use of compelled self-incriminating statements "against" a defendant; the Fourth Amendment can be furthered by an exclusionary rule, while the Fifth Amendment is itself an exclusionary rule. Dershowitz \& Ely, Harris v. New York: Some Anxious Observations on the Candor and Logic of the Emerging Nixon Majority, 80 YALE L.J. 1198, 1214 (1971).

81. See p. 353 supra. Cf. Massiah v. United States, 377 U.S. 201, 206-07 (1964) (continuing undercover investigation was proper even though defendant's incriminating statements could not be used against him without violating his right to counsel).

82. See p. 355 supra.

83. See note 68 supra (describing police discretion).

84. Cf. State v. Sickels, 275 N.W.2d 809 (Minn. 1979) (police exercised proper discretion in taking intoxicated and suicidal individual to detoxification center but should have administered $M F$ randa warnings before asking questions about unrelated crime in order to protect suspect's constitutional rights). 
ments made before a formal arrest is consummated in a standoff situation. Once the crisis has subsided and the standoff suspect is in the form of custody that the Miranda Court envisioned, no countervailing policy goals persist; the police can administer Miranda warnings safely and then proceed with a conventional interrogation..$^{85}$

Opponents of the Miranda decision have often argued that the requirement of warnings creates an unacceptable barrier to the investigation of crime. ${ }^{86}$ The rule proposed here would doubtless elicit similar objections. ${ }^{87}$ But under this rule, standard interrogation procedures would remain available to the police after the standoff suspect surrendered. There is no reason to believe that the suspect who has confessed during a standoff is any more likely to invoke his Miranda rights after surrender than the suspect who undergoes a conventional arrest. Admittedly, information obtained incident to the standoff negotiations may be lost under this rule. But the need to resolve these crises peacefully outweighs the need to protect the admissibility of that evidence, which in most cases will not be essential for conviction. ${ }^{88}$

\section{B. Judicial Authority to Implement a Per Se Ban}

Although policy considerations prompt the per se exclusionary rule that this Note proposes, the authority of courts to impose it derives from their power to establish rules that further the enforcement of constitutional rights. $^{89}$ Miranda warnings are only one method of protecting Fifth

85. In order to conform with the Miranda decision's requirement that the suspect understand the nature of his constitutional rights, however, the police should be required to supplement the traditional warnings with an additional admonition that nothing the suspect has said during the surrender negotiations may be used against him in court. Cf. Dix, Mistake, Ignorance, Expectation of Benefit, and the Modern Law of Confessions, 1975 WASH. U.L.Q. 275, 358 (person who voluntarily confesses to robbery without knowing that this crime also involved a killing should be instructed of this fact, warned in accordance with Miranda, and told that his initial statement cannot be used against him).

86. See Miranda v. Arizona, 384 U.S. 436, 500 (1966) (Clark, J., dissenting in part and concurring in part) (voicing fear that decision would weaken law enforcement efforts); id. at 517 (Harlan, J., dissenting) (same); id. at 541 (White, J., dissenting) (same); H. FRIENDLY, supra note 77, at 27576; Inbau, Law Enforcement, the Courts, and Individual Liberties, in CRIMINAL JUSTICE IN OUR TIME 97, 108 ( $\Lambda$. Howard ed. 1965) (requirement that suspect be advised of right to silence and right to counsel will result in fewer convictions). Empirical studies of the impact of Miranda, however, suggest that it has not interfered with criminal investigations. See, e.g., O. STEPHENS, supra note 48, at 168; Project, Interrogations in New Haven: The Impact of Miranda, 76 YALE L.J. 1519, 1613 (1967).

87. Cf. 26 VILL. L. REV. 682, 697 (1981) (Third Circuit decision in Mesa reflects desire to avoid unnecessarily hampering police).

88. The fact that the police already have probable cause to make the arrest demonstrates the ancillary nature of confessions in standoff situations. See p. 356 supra. In Mesa, for example, two eyewitness victims had informed the FBI that the suspect had shot them. Furthermore, standoff situations that occur at the scene of a crime will frequently contain a great deal of physical evidence whose admissibility the rule will not affect. The rule only reaches evidence that arises directly from the surrender negotiations themselves.

89. See Bivens v. Six Unknown Named $A$ gents of Federal Bureau of Narcotics, 403 U.S. 388, 407 
Amendment rights. The judiciary may reject that method in favor of other devices if its use would threaten independent policy concerns, and if the alternatives are equally effective in furthering the constitutional values at stake. The Court has implicitly acknowledged its power to weigh policy considerations when designing remedies to vindicate constitutional provisions $^{90}$ in such contexts as illegal searches by police, ${ }^{91}$ employment discrimination on sexual grounds by members of Congress, ${ }^{92}$ failure of prison officials to provide adequate medical attention for inmates, ${ }^{93}$ and school desegregation. ${ }^{94}$ In standoff situations, this approach dictates the selection of a pure exclusionary rule instead of a rule that would encourage the police to abdicate essential peacekeeping functions. ${ }^{95}$

The Miranda Court recognized that a warnings procedure was not the only possible solution to the Fifth Amendment problem of coerced confessions. In fact, the Court indicated that it considered the warnings the minimum level of protection required to secure the right against self-incrimination. ${ }^{96}$ Thus, the courts should be free to select any other protective

(1971) (Harlan, J., concurring) (judiciary has particular responsibility to assure vindication of constitutional rights).

90. See Fiss, Foreword: The Forms of Justice, 93 HARV. L. REV. 1 (1979) (to give meaning to constitutional values, courts can design remedies similar in scope to policy measures prescribed by the executive and legislative branches); Dellinger, Of Rights and Remedies: The Constitution as a Sword, 85 HARV. L. REV. 1532, 1534 (1972) (judiciary should have prerogative to prescribe remedies that fulfill constitutional norms).

91. See Bivens v. Six Unknown Named Agents of Federal Bureau of Narcotics, 403 U.S. 388 (1971) (deriving damages remedy from Fourth Amendment right against unreasonable searches and seizures).

92. See Davis v. Passman, 442 U.S. 228 (1979) (deriving damages remedy from due process clause of Fifth Amendment).

93. See Carlson v. Green, 446 U.S. 14 (1980) (deriving damages remedy from Eighth Amendment prohibition of cruel and unusual punishment).

94. The weighing of policy choices in designing remedies under the Fourteenth Amendment is especially apparent in school desegregation cases. For example, in Swann v. Charlotte-Mecklenburg Bd. of Educ., 402 U.S. 1, 30-31 (1971), the Court recognized that busing of children to achieve school desegregation might, under certain circumstances, pose a "risk [to] the health of the children or significantly impinge on the educational process." The Court went on to suggest that many factors and competing values must be considered in determining the appropriateness of a particular busing plan, and then proceeded to order such a plan.

95. The most troublesome case challenging the legitimacy of the per se rule proposed in this Note would be one where the police administered Miranda warnings to a standoff suspect who subsequently waived his rights and made incriminating statements to the police before surrendering. Unless the suspect could later successfully attack the validity of his waiver, see Johnson v. Zerbst, 304 U.S. 458 (1938) (establishing that waiver of Sixth Amendment right to counsel must be "intelligent"); see also Miranda v. Arizona, 384 U.S. 436, 475 (1966) (applying rigorous Zerbst standards to custodial interrogation); note 73 supra (questioning constitutional efficacy of Miranda warnings in standoff situations), the court would be in the position of barring a constitutionally valid confession on pure policy grounds. Despite this anomaly, the important objective of lending guidance to the police for future standoff situations militates in favor of upholding the per se rule.

96. 384 U.S. at 467 (any other custodial interrogation procedures must be "at least as effective in apprising accused persons of their right of silence and in assuring a continuous opportunity to exercise it") (emphasis supplied). Cf. Dellinger, supra note 90, at 1560-61 (Congress may replace Fourth Amendment exclusionary rule with substantive remedy that would "provide comparable vindication of the interests protected by the displaced remedy.") 
device that would preserve Fifth Amendment rights at least as well as do the warnings. The per se exclusionary rule should be adopted because it provides the greatest amount of protection possible.

\section{Related Settings}

The concerns that make application of traditional analysis difficult in the standoff situation may be present as well in a variety of other criminal justice settings in which the verbal cooperation of the defendant is required. For example, it is sometimes necessary or desirable to obtain information from a defendant in order to determine custody status, ${ }^{97}$ evaluate competency to stand trial, ${ }^{98}$ conduct plea bargaining, ${ }^{99}$ and impose sentence. ${ }^{100}$ All of these processes involve the collection of data to determine the proper treatment for the defendant within the system. Just as peaceful resolution of a standoff situation may require a "friendly" conversation, ${ }^{101}$ so efficient gathering of essential data may depend on a con-

97. See People v. Brown, 438 N.Y.S.2d 955, 957 (N.Y. Sup. Ct. 1981) (statement defendant made during prearraignment interview used to determine eligibility for recognizance or bail release held inadmissible in government's case-in-chief "as a matter of public policy and fundamental fairness"); see also Killough v. United States, 336 F.2d 929, 932 (D.C. Cir. 1964) (statements made during interview of suspect by prison employee for purpose of determining proper custody classification held inadmissible); Harrison v. United States, 359 F.2d 214, 219 (D.C. Cir. 1965) (same).

98. See p. 361 infra.

99. Effective plea bargaining requires a candid exchange between prosecutor and defendant regarding the facts surrounding the crime charged. People v. Tanner, 45 Cal. App. 3d 345, 351, 119 Cal. Rptr. 407, 411 (1975) (letters from defendant to prosecutors during course of bona fide plea negotiations held inadmissible). Discouraging such a candid exchange would frustrate the goal of atlaining settlements. Id. Cf. People v. Campbell, 66 Cal. App. 3d 806, 808, 136 Cal. Rptr. 149, 150 (1977) (admission of confession in transcript of Municipal Court arraignment proceeding held grounds for reversal of conviction). But cf. State v. Harris, 147 Conn. 589, 164 A.2d 399 (1960) (statements made by defendant before institution of criminal proceedings during conferences defendant instigated in order to persuade state's attorney not to prosecute held admissible).

100. FED. R. CRIM. P. 32(c)(1) authorizes the probation office to conduct a presentence investigation of a defendant's character and background in order to assist the court in pronouncing sentence. The investigation consists in large part of an interview of the defendant by a probation officer. The rule specifies that the report resulting from the presentence investigation "shall not be submitted to the court or its contents disclosed to anyone unless the defendant has pleaded guilty or nolo contendere or has been found guilty." The rule thus guards against possible prejudice that would result from premature use of presentence investigation reports, see Gregg v. United States, 394 U.S. 489, 492 (1969); United States v. Warren, No. 79-162 (D.C. Oct. 9, 1981), and encourages suspects to speak freely during their interviews, cf. People v. Hicks, 4 Cal. 3d 757, 763, 94 Cal. Rptr. 393, 396, 484 P.2d 65, 68 (1971) (if defendants knew that damaging admissions to probation officers could be used against them in another trial, they would not talk freely and purpose of interview would be frustrated). Compare People v. Garcia, 240 Cal. App. 2d 9, 13, 49 Cal. Rptr. 146, 148 (1966) (upholding admissibility of voluntary statements made by defendant to probation officer before sentencing but criticizing use of such statements on policy grounds) with People v. Quinn, $61 \mathrm{Cal}$. 2d 551, 554, 39 Cal. Rptr. 393, 395, 393 P.2d 705, 707 (1964) (statements by defendant to probation officer after guilty plea held involuntary because they were extracted by threat not to recommend leniency).

101. See p. 346 supra. A similar tension exists in conversations between parole officers and parolees, see State v. Lekas, 201 Kan. 579, 583, 442 P.2d 11, 15 (1968) (parole officer must give warnings in order to preserve admissibility of defendant's statements), and conversations between probation officers and probationers, see State v. Johnson, 87 S.D. 43, 46, 202 N.W.2d 132, 134 (1972) (probationer's statements to probation officer admissible because requiring Miranda warnings would frus- 
genial, non-antagonistic interaction between an official and a defendant. The rule proposed here might, therefore, be extended to encompass these settings. For example, the per se exclusionary rule might have been applied profitably in the recent case of Estelle v. Smith. ${ }^{102}$ In that case, the state employed a psychiatrist to determine the competency of a criminal defendant to stand trial and attempted to use the defendant's statements to the psychiatrist at the sentencing phase of the trial as evidence that the defendant would pose a future threat to society. ${ }^{103}$ The Supreme Court held that the Fifth Amendment precluded such use of the statements. ${ }^{104}$ At the same time, however, the Court held that the state may use the same answers for competency determination purposes without constitutional violation. ${ }^{105}$ As a result, the legitimate policy goal of evaluating competency is furthered without any compromise of the right against self-incrimination. On the other hand, the Smith decision seems to create a variation of the standoff dilemma ${ }^{106}$ for the psychiatrist conducting the competency examination. Under Smith, the psychiatrist can preserve the admissibility of the defendant's statements by administering Miranda warnings and procuring a waiver from the defendant. ${ }^{107}$ Giving the warnings, however, may lead the defendant to become uncooperative and thus frustrate the government's purpose in conducting the examination. Extension of the per se exclusionary rule to this setting would, as in the standoff case, extinguish the dilemma by recognizing the inappropriateness of warnings. Were the government not permitted to retain an interest in using the interview for incriminatory purposes, the competency examination could proceed without difficulty.

\section{Conclusion}

In Miranda, the Supreme Court acknowledged that criminal suspects are subject to coercion during custodial police interrogation. In order to protect the suspect's opportunity to assert his Fifth Amendment right against self-incrimination, it held that the police must inform the suspect

trate rehabilitative purpose of probation).

102. $101 \mathrm{~S}$. Ct. 1866 (1981).

103. For capital cases, Texas law requires that the jury decide the issues of guilt and penalty in separate proceedings. In the sentencing phase of the trial, the jury considers three questions, which, if answered affirmatively, result in mandatory imposition of the death penalty. TEX. CODE CRIM. PROC. ANN. art. 37.071 (Vernon 1981). One of these questions is "whether there is a probability that the defendant would commit criminal acts of violence that would constitute a continuing threat to society." Id. art. 37.071(b)(2).

104. Id. at 1872-73.

105. Id. at 1876. Contra, Note, Requiring a Criminal Defendant to Submit to a Government Psychiatric Examination: An Invasion of the Privilege Against Self-Incrimination, 83 HARV. L. REV. 648 (1970).

106. See p. 349 supra.

107. 101 S. Ct. at 1876. 
of his rights and warn him of the consequences of waiving them. The Court did not, however, declare unconstitutional any particular interrogation techniques.

The standoff situation presents the same danger of coercion that existed in the custodial interrogation setting in Miranda. Yet, in the standoff situation, Miranda warnings prove an ill-advised and perhaps ineffective solution to the problem. ${ }^{108} \mathrm{~A}$ per se rule against the admissibility of a standoff suspect's pre-arrest statements would simultaneously protect his opportunity to invoke his rights, and encourage the police to pursue the desirable policy of peaceful crisis resolution.

108. See note 73 supra. 